\title{
NEW REVIVALISME ISLAM
}

\author{
Murkilim \\ Dosen IAIN Bengkulu \\ Jln Raden Fatah Pagar Dewa Bengkulu \\ Email: murkilim@iainbengkulu.ac.id
}

\begin{abstract}
New Islamic revivalism is a contemporary Islamic thought movement that seeks to cleanse and restore the understanding and practice of Islamic teachings to pure Islam. New Revivalism arises because of the internal problems of Muslims and External and Western modem influences. New Revivalism in Pakistan emerged under the main character of Abul 'A'la Al-Mawdudi with the idea that the life of Muslims should be governed by Islamic teachings in an Islamic state, which takes the form of "theo democracy". For the realization of such a state, a gradual Islamic revolution should be undertaken, by first doing the Islamization of society. Hasan Al Bana with Kaffahnya Islamic concept through lkhwanu Muslimin trying to make it happen by utilizing all available potential, either individually or institutionally, so that Islam becomes a comprehensive, universal ldiology based on the original source; Al-qur'an and Sunnah. The Muslim Brotherhood movement became radicalized in the hands of Sayyid Qutub, so ready to conduct jihad fisabilillah. In Indonesia also found the movement of Revivalism both in the form of premodernist and postmodernist among others is padri movement, Muhammadiyah, The United of Islam, and in the form of more now among others is Jamaat Islam and Darul Arkam.
\end{abstract}

Keywords: revivalism, Islam

Abstrak: New revivalisme Islam adalah gerakan pemikiran Islam Kontemporer yang berusaha membersihkan dan mengembalikan pemahaman dan pengamalan ajaran Islam kepada Islam murni. New Revivalisme muncul disebabkan oleh permasalahan-permasalahan internal umat Islam dan Ekstemal dan pengaruh barat modem. New Revivalisme di Pakistan muncul dibawah bumbingan tokoh utamanya yaitu Abul 'A'la Al Maududi dengan pendapat bahwa kehidupan umat Islam haruslah diatur berdasarkan ajaran Islam dalam suatu negara Islam, yang berbentuk "theo demokrasi". Untuk terwujudnya negara yang demikian, perlu dilakukan revolusi Islam secara gradual, dengan terlebih dahulu melakukan Islamisasi masyarakat. Hasan Al Bana dengan konsep Islam Kaffahnya melalui lkhwanu Muslimin berusaha mewujudkannya dengan mendaya gunakan semua potensi yang ada, baik secara individu maupun secara kelembagaan, sehingga Islam menjadi ldiologi yang konfrehensif, universal berdasarkan sumber aslinya; Al-qur'an dan Sunnah. Gerakan lkhwanu Muslimin menjadi radikal ditangan Sayyid Qutub, sehingga siap melakukan jihad fisabilillah. Di Indonesia juga ditemukan gerakan Revivalisme baik dalam bentuknya pramodernis maupun pascamodernis antara lain adalah gerakan padri, Muhammadiyah, Persatuan Islam, dan dalam bentuk yang lebih kini antara lain adalah Islam Jamaah dan Darul Arkam.

Kata kunci: revivalisme, Islam

\section{Pendahuluan}

Keberadaan revivalisme dalam Islam adalah sebuah tuntutan dari sejarah panjang perjalanan Islam, yang telah malang melintang melewati batas geografis dan lintas budaya masyarakat Islam di seantero jagad raya ini, dan telah mengalami pasang naik dan pasang surutnya.

Terjadinya saling mempengaruhi antara Islam dengan budaya masyarakat yang dimasukinya adalah suatu keniscayaan. Dalam hal ini, pengaruh yang terjadi ada kalanya bersifat positif dan juga ada yang bersifat negatif. Contohnya adalah Islam di Indonesia, yang dalam proses masuk dan berkembangnya berjalan secara damai, sehingga banyak ditemukan pengaruh budaya masyarakat sebelum Islam datang. Diantaranya adalah tradisi membakar kemenyan pada waktu akan berdo'a, acara menujuh hari dalam acara kematian, mengadakan saji-sajian dan sebagainya yang terdapat dalam masyarakat. Dan ini telah mengundang perdebatan panjang

164 NUANSA Vol. X, No. 2, Desember 2017 
dalam masyarakat yang nota bene melakukan pemikiran yang ingin mengembalikan kepada "Islam yang murni".

Hal yang sama juga terjadi ketika Islam bersentuhan dengan peradaban barat modem baik dari segi sosial budaya, politik, ekonomi dan lainnya. Kondisi dan situasi yang demikian telah pula mendorong munculnya pemikiran-pemikiran yang ingin menempatkan Islam dalam bentuknya yang murni. Pemikiran-pemikiran itu tidak hanya eksis dalam bentuk sebuah wacana, tetapi telah mencapai bentuk praktek. Gerakan pemikiran yang berupaya mengembalikan Islam kedalam bentuknya yang semula, sebagaimana yang terjadi pada masa Rasullullah SAW dan Khulaffahurrasyidin, yang dikenal dengan istilah revivalisme. Dalam makalah ini akan dibahas gerakan revivalisme ini dalam bentuk kekinian (kontemporer) dengan judul "NeoRevivalisme Islam “.

\section{Pembahasan}

Dari sudut bahasa revivalisme berasal dari revival yang berarti "penghidupkan kembali dan kebangkitan kembali (Peter Salim, 1996: 1655). Peletakan kata •neo" (baru) kepada "revivalis" ("kebangkitan kembali") mengisyaratkan bahwa revivalisme kontemporer mempunyai kontinuitas dengan revivalisme dimasa lampau (Azra, 1999:46).

Fazlur Rachman (1919-1998) seorang pemikir Islam kontemporer, ketika mempetakan perkembangan pemikiran pembaharuan dalam Islam membagi kepada beberapa bentuk tipologi: pertama, revivalis pramodernis, muncul pada abad ke-18 dan 19 di Arabia, India dan Pakistan. Kedua, modernis klasik yang muncul pada pertengahan abad ke-19 dan awal abad ke-20 di bawah pengaruh ide ide barat. Ketiga, revivalisme pasca modernis, yang kemunculannya merupakan reaksi dari gerakan sebelumnya. Keempat, neo modernis (Amir, 1999: 15-16).

Spektrum gerakan revivalisme Islam sangat luas, mencakup gerakan-gerakan yang sekedar antusiasme keIslaman sampai kepada fundamental isme yang bisa berujung pada militanisme dan radikalisme. Lebih tegas lagi, revivalisme dapat mengejawantahkan diri secara sederhana dalam bentuk intensifikasi penghayatan dan pengamalan Islam yang sering bersifat individual dan pembentukan kelompok atau gerakan terkoordinasi yang bertujuan membangkitkan kembali Islam dengan caracara damai, sampai kepada gerakan fundamental isme yang ingin membangun sistem sosial budaya, politik dan ekonomi yang mereka pandang lebih 1slami (Azra, 1999:47).
Revivalisme pasca modernis menurut Azra dapat disebut revivalisme kontemporer (Neo Revivalisme). Jadi neo revivalisme adalah gerakan pemikiran Islam kontemporer yang berusaha mengembalikan pemahaman dan pengamalan Islam secara murni baik dalam bemtuk wacana maupun dalam bentuk praktek.

\section{Latar Belakang dan Ciri-Ciri Revivalisme}

Keberadaan neo revivalisme adalah merupakan kelanjutan dari revivalisme pra modernisme, sekalipun permasalahannya tidak persis sama, revivalisme pra modernisme muncul murni masalah internal umat Islam. Sementara kemunculan neo revivalisme Islam secara sosiologis bahkan jauh lebih komplek dibandingkan revivalisme pra modernisme. Selain disebabkan faktor internal umat muslimin sendiri, juga faktor ekstemal, persisnya tantangan Barat ( Az.ra 1999: 47 ).

Gerakan revivalisme dapat diidentifikasi melalui ciri umum yang dimiliki oleh kedua tipologi revivalisme yaitu, revivalisme pra modernisme dan pasca modernisme. Ciri umum pertama bahwa gerakan-gerakan revivalisme menyerukan kembali kepada Islam yang “mumi” - yang “orisinal”. Kedua, gerakan revivalisme pada umumnya menghimbau penerapan dan pengembangan Ijtihad khususnya dalam masalah-masalah yang berkaitan dengan hukum dan menolak taqlid.

Selain memiliki kedua ciri umum tersebut di atas gerakan gerakan revivalisme juga memiliki dua karakter. Pertama, keharusan melakukan "hijrah" dari wilayah yang didominasi tidak hanya oleh orang-orang kafir dan musyrik, tetapi juga oleh muslim lain yang tidak sejalan dengan pandangan gerakan revivalisme bersangkutan . Kedua, diantara gerakan revivalisme mempunyai kepercayaan yang kuat kepada kepemimpinan tunggal, apakah dalam bentuk amir atau imam.

\section{Neo Revivalisme dalam Wacana dan Praktek}

Gerakan-gerakan pemikiran yang kontemporer yang berusaha untuk mengembalikan pemahaman dan pengamalan I Islam sebagaimana dicontohkan oleh rasulullah dan kaum salaf yang dikenal dengan neo revivalisme. Di antara tokoh-tokohnya adalah;

Abul A'la Al Maududi di Pakistan dengan Jama'at Al 1slamnya, di Mesir Hasan Al Banna, Sayyid Qutup dengan lkhwanul Muslimin dan di Indonesia antara lain dikenal Ahmad Dahlan dengan Muhammadiyah dan Ahmad Hasan dengan Persis.

Sebagaimana telah diungkapkan pada pembahasan terdahulu bahwa kemunculan revivalisme 
kontemporer dilatar belakangi oleh kondisi internal umat Islam dan sekaligus juga faktor eksternal berupa pengaruh dunia barat. Interaksi, penetrasi dan akhimya penjajahan barat atas hampir seluruh wilayah muslim dalam masa modem tidak hanya mengakibatkan disintegrasi politik muslim, tetapi juga menimbulkan pergumulan yang cukup intens dikalangan kaum muslimin sendiri (Azra 1996: 114). Kekuatan dan kekuasaan barat dalam lapangan kehidupan telah mendorong lahimya usaha-usaha pembaharuan dikalangan pemikir Muslim.

Hancurnya gerakan Kilafah pada tahun 1924, telah memberikan pengaruh yang besar terhadap Maududi. Dia menolak faham nasionalisme yang dalam pandangannya telah menyesatkan muslim Turki dan Mesir dan menghancurkan kesatuan muslim dengan cara menolak imperium Usmaniah dan Khilafah Muslim. Demikian juga pandangannya terhadap Nasionalisme India yang sempit, yang tak lebih hanya untuk kepentingan Hindu. Konsekwensi dari pandangan ini, membawa dia keluar dari Jama'at (masyarakat ulama India).

Keluamya Maududi dari Jami'at telah memberi peluang baginya untuk mengembangka:i konsepnya sebagai jawaban terhadap nasionalisme. Oia menganjurkan aksi 1slami, bukannya nasionalis, dalam menentang imperialisme, karena aksi seperti ini akan melindungi kepentingan Muslim dan sekaligus memberikan tempat bagi wacana kebangkitan. (Rahmena 1996: 105).

Bagi Maududi pergulatan antara Islam dan kekhufuran berpuncak pada revolusi Islam dan berdirinya negara Islam. Dalam kerangka pemikiran berdirinya negara Islam, berdirinya negara Islam itu haruslah berdasarkan kehendak umat, untuk itu umat harus diperkenalkan kepada Islam yang mumi. Kaum muslimin akan menghendaki negara Islam, kalau mengetahui ajaran Islam sejati dan keefektifan negara Islam. Berdirinya negara Islam adalah puncak dakwah yang sukses. (Rahmena 1996: 110).

Negara akan berhasil dengan baik apabila mendapatkan legetimasi dan dukungan yang utuh dari masyarakat. Karenanya sebelum mendirikan negara Islam terlebih dahulu harus dilakukan Islamisasi terhadap masyarakat. 1slamisasi negara tanpa Islamisasi masyarakat akan melahirkan negara yang otokrasi, memaksakan kehendaknya kepada masyarakat yang belum siap dan keberatan. Karena alasan inilah Maududi banyak menekankan pendidikan dan memandang reolusi Islam sebagai upaya gradual (Rahmena 1996:111).

Negara Islam dalam konsep Maududi mem- punyai ciri-ciri khas yang membedakannya dari sistem negara lainnya ialah : 1 . Kekuasaan perundang-undangan llahi. 2. Keadilan antara manusia. 3. Persamaan antara kaum muslimin. 4. Tanggung jawab pemerintah. 5. Permusyawaratan. 6. Ketaatan dalam kebajikan. 7. Berusaha mencari kekuasaan untuk diri sendiri adalah terlarang. 8. Tujuan adanya negara. 9. Amr bil- makruf nahyu anil- mungkar (Maududi 1998: 93- 106).

Negara dengan ciri-ciri tersebut di atas disebut oleh Maududi dengan “Theo-Demokrasi". Dengan konsep the demokrasi ia berpendapat bahwa hanya Tuhan lah yang berdaulat, dan manusia adalah sebagai khalifah. Dengan demikian dia menolak negara demokrasi, dimana kekuasaan tertinggi berada ditangan rakyat. Untuk mempraktekkan konsep-konsepnya Maududi membangun suatu partai yang diberinya nama Jama'at Al- 1slami. Maududi menolak mengakomodasi Partai Kongres, karena ia percaya bahwa partai kongres adalah sekular dan secara implisit memberikan janji untuk menclirikan pemerintahan Hindu, yang berarti akhir Islam di India. Maududi juga, jika bukan lebih, menentang Liga Muslim yang menurutnya merupakan entitas sekularis yang sepenuhnya tak mampu menjawab hal-hal penting bagi tanah air Muslim. (Rahmena 1996: 115).

Menyadari kenyataan yang demikian, untuk mengimplementasikan konsep dan visi idiologinya Maududi mendirikan suatu partai Jama'at Al-1slami, didukung oleh dua orang ulama muda yang mempunyai popularitas tinggi yaitu Maulana Sayyid Abul Hassan Ali Nadawi dan Muhammad Mansyur Nu'mani. Partai ini dideklarasikan di Lahore tahun 1941 yang dihadiri oleh 70 orang, Maududi sebagai Amir (Presiden) Jama'at selama 31 tahun (19411972).

Semenjak dari awal melalui partai Jama'at Al1slami Maududi telah mengarahkan kaum muslimin untuk memulai revolusi Islam, untuk membentuk masyarakat dan politik yang sesuai dengan ajaran Islam sebagaimana yang telah diinterpretasikan dalam wacana Negara Islam oleh Maududi. Diantara tujuan jangka pendek Jama'at adalah menjaga kepentingan Islam di medan politik dan meinbendung kekuatan sekuler supaya tidak melakukan konsulidasi kekuasaan.

Semenjak terpisahnyaIndia, dan Pakistan menjadi negara baru, partai Jama'at al-lslami mendapat peluang untuk menerapkan program politiknya. Maududi dengan jema'at lslamnya telah malang melintang dalam dunia politik Pakistan yang dalam romantikanya membuat ia keluar masuk penjara. Gerakan-gerakan 
yang dilakukan Maududi pada dasamya adalah bagaimana Islam eksis dalam bentuknya yang mumi dalam segala sisi dan dimensinya.

Organisasi lkhwan Nur Muslimin yang didirikan oleh Hasan Al Banna (1906-1949) pada tahun 1928 adalah merupakan gerakan yang paling berpengaruh yang mengarahkan kembali Muslim ketatanan Islam yang mumi. Organisasi ini lahir ditengah-tengah kehidupan kaum muslimin yang parsialis dan maaing-masing merasakan merekalah yang benar. Dalam masalah politik secara umum berpaham nasionalis sekuler. Dominasi politik dan ekonomi Eropa disertai dengan dominasi budaya terlihat pada kecenderungan elite Mesir untuk bergaya hidup Barat dan unluk memungut gagasan Barat, meski dengan mengorbankan dan praktek tradisional Islam. (Rahmena, 1996:128). Kenyataan ini memberikan kesempatan dan memantapkan Hassan Al-Banna untuk mengembangkan konsep Islam Kaffah dan membangkitkan gerakan lkhwan Nur-Muslimin. Sampai terjadinya revolusi Palestina, lkhwan Al-Muslimin tidak lebih dari sebuah organisasi "gurem" dan pendirinya Hasan A1Banna tidak lebih dari seorang Mubaligh yang sibuk den-gan masalah-masalah moral ketimbang politik.

Revolusi Palestina memberikan kesempatan emas bagi lkhwan Al-Muslimin untuk tampil ke pentas politik Arab. lkhwan Nur-Muslimin mengorganisasi besar-besaran memprotes lnggris dan perwakilan perwakilannya di Timur Tengah. Pemogokan umum bangsa Arab pada 1936-1939 mentransformasi lkhwan Al-Musl imin dari sekedar organisasi pemuda menjadi organisasi politik (1939) (Azra,1996:116).

Al-Banna percaya kelemahan dan kerentanan muslimin terhadap dominasi Eropa disebabkan oleh penyimpangan kaum muslimin dari Islam sejati. Untuk membangkitkan Mesir, kaum muslimin harus bertekad unluk kembali memahami dan hidup menurut Islam seperti yang di tegaskan dalam Al-Qur'an dan Sunnah, dan dicontohkan generasi-generasi pertama Muslim (Salaf).

Konsepsi Islam sejatinya Al-Banna menuntut disucikannya keyakinan dan praktek keagamaan yang ada. Kaum muslimin dalam beribadah, haruslah berdasarkan pada kitab suci, dan jangan lagi mempercayai kemujaraban ajimat, jampi-jampi, mantra, dan ramalan. Secara umum, kaum muslimin harus memerangi bid'ah dalam praklek agama. Siapapun bisa disebut Muslim, kalau dia mengakui percaya kepada Allah dan kenabian Muhammad, berbuat sesuai dengan kepercayaannya itu dan menunaikan kewajiban agama. Bahwa yang disebut kafir itu adalah orang yang terang-terangan menyatakan murtad, mengingkari keyakinan dan praktek yang lazim dikenal sebagai bagian dari Islam dan sengaja mendistorsi arti Al-Qur'an. (Rahmena, 1996:136).

Pada intinya Al-Banna merumuskan ideologi lkhwan Al-Muslimin yang menekankan kemampuan Islam sebagai ideologi yang total dan komprehensif. Program lkhwan Al-Muslimin kemudian didasarkan pada tiga pandangan dasar : Perlama, Islam adalah sistem komprehensif yang mampu berkembang sendiri; ia merupakan jalan mutlak kehidupan dalam seluruh aspeknya; kedua, Islam memancar dari dua sumber fundamental yakni Al-Qur'an dan Hadits; ketiga, Islam berlaku untuk segala waktu dan tempat. Ada dua program lkhwan Al-Muslimin, Perlama, "Internasionalisasi organisasi guna membebaskan seluruh wilayah Muslim dari kekuasaan dan pengaruh asing. Kedua, membangun diwilayah Muslim yang telah dibebaskan itu pemerintahan Islam, yang mempraktekkan prinsip-prinsip Islam menerapkan sistem sosialnya secara menyeluruh (Azra, 1996:119).

Gerakan lkhwan Al-Muslimin berusaha melakukan Islamisasi masyarakat melalui berbagai pendekatan, individu, kelompok dan kelembagaan. Al-Banna selalu menekankan bahwa semangat aktivisme di semua bidang kehidupan mutlak panting. Untuk mewujudkan visi 1slamnya yang merupakan kerangka menyeluruh bagi aksi individu dan kelompok dalam sebuah essay yang terbit 1934 Al-Banna melukiskan aktivitas lkhwan Al-Muslimin di berbagai bagian Mesir, seperti mendirikan sekolah untuk anak laki-laki, anak perempuan, dan pekerja: membangun Masjid dan pabrik tekstil; membentuk klub amal untuk membantu fakir miskin; berbicara dikedai kopi, tempat umum, pesta dan ditempat jaga. (Rahmena 1996;149).

Al-Banna berusaha memanfaatkan berbagai potensi yang ada secara maksimal untuk mencapai Islam yang Kaffah, tidak ada yang menghentikan aktivitas Al-Banna sehingga dia dibunuh oleh agen agen pemerintah Mesir pada 12 Februari 1949 (Azra, 1996:117).

Sepeninggal Al-Banna, kedudukan tokoh sentral 1khwan Al Muslimin dipegang oleh Sayyid Qutub (1906-1966), yang pada masa kepemimpinannya gerakan ini terkesan fundamental isme dalam mentransformasi kepercayaan ideologi, sehingga gerakan siap untuk mengangkat senjata. Hal ini terlihat pada pandangan-pandangannya yang fundamental, seperti konsep Jahilliyah Modem" yang ditransfer dari konsep Abul A'la Al-Maududi dan 
menemukan format yang sempuma pada muridnya Abu Al-Hasan Ali Al-Nadwi (Azra, 1996: 118-120).

Konsep Jahilliyah modem ini bagi Sayyid Qutub tidak hanya sebatas persoalan hukum, tetapi lebih luas dari itu termasuk juga aspek politik dan pada hakekatnya ia menolak secara total modernisme yang dianggap kriteria buatan dari manusia. Seiring dengan itu dimunculkannya sikap hifrah dan taqfir, yaitu konsep aksi untuk memisahkan diri dari masyarakat umum untuk membentuk komunitas muslim tersendiri (Azra, 2001:50-53) .

Setelah dianalisa beberapa uraian diatas terlihat adanya pergeseran paradigma dari kepemimpinan Hasan Al-Banna kepada Sayyid Qutub. Pergeseran tersebut lebih mengarah kepada fundamental isme yang terkadang radikalisme, seperti yang terlihat pada perkembangan selanjutnya dari lkhwan AlMuslimin yang terbagi dua, yaitu kubu moderat dan kubu revolusioner.

Di Indonesia juga ditemukan gerakan-gerakan revivalisme baik dalam bentuk pramodermis maupun pascamordemis. Revivalis pramordemis contohnya gerakan Padri di Minangkabau pada awal abad ke-19. Gerakan ini mengalami proses radikalisasi, khususnya setelah kembalinya 3 Haji (H. Miskin, H. Sumanik, dan H. Piobang) dari tanah suci. Gerakan Padri pada intinya bertujuan melakukan pemumian terhadap penghayatan dan pengamalan Islam di Minang Kabau yang menurut pandangan mereka tidak sesuai lagi dengan ajaran Islam yang mumi. (Azra 1996: 49)

Muhammadiyah dengan tokoh utamanya Ahmad Dahlan, yang dalam gerakannya menentang taqlid dan mendorong untuk mengembangkan ijtihad, dan berusaha membersihkan pemahaman dan pengamalan Islam dari tahyul, khurafat dan bid'ah dalam kehidupan umat Islam Indonesia untuk dikembalikan kepada ajaran Islam yang mumi, sebagaimana yang dilaksanakan Rasulullah dan kaum salaf adalah termasuk kedalam gerakan new revivalisme.

Persatuan Islam (Persis) yang didirikan di Bandung pada tanggal 12 September 1923 oleh kelompok study Islam, yang dipimpin oleh Zam-zam dan Muhammad Yunus yang kemudian berkembang dibawah pimpinan Ahmad Hasan juga dapat disebut New Revivalisme. Karena Persis berdiri termotivasi oleh pemikiran pembaharuan dari dunia Arab, Saudi Arabia dan Mesir mempunyai peranan besar dalam memberikan inspirasi mendirikan gerakan gerakan untuk kembali kepada Al-qur'an dan Sunnah. Pengaruh itu lebih tampak pada persatuan Islam dengan radikalismenya yang hampir- hampir sejenis dengan gerakan Wahabi. Dan yang tidak kalah pentingnya yang telah mendorong lahimya persatuan Islam adalah kondisi umat yang dalam pandangan mereka, telah mengalami kemunduran. Kemunduran umat Islam disebabkan masuknya paham paham yang tidak berpangkal pada Al-qur'an dan As Sunnah, sikap taqlid, mengikuti imam dan Mazhab dengan membuta. Dalam rangka mencapai tujuan yang telah dicita-citakan Persis mengadakan kelompok kajian Islam, diantara pesertanya adalah Muhammad Natsir, Fakhrudin Al Khairi, Ruspandi, Caya dll. Pada tahun 1930 Persis mendirikan Pendidikan Islam, sekolah itu dipimpin oleh Muhammad Nalsir. Pada tahun 1932 mendirikan Kweeks School di Bandung. Pada bulan Maret 1936 didirikan pesantren Persatuan Islam di Bandung. Pada Februari 1941 dibuka pesantren putri di Bangil. Persis telah pula menerbitkan beberapa majalah : Majalah Pembela Islam, Oktober 1929, AlFatwa November 1931, Al-Lisan 27 Desember 1935, A1 Muslimin 1945 dan Aliran Islam 1948.

Semua usaha yang dilakukan oleh Persatuan Islam tersebut adalah dalam rangka upaya pembersihan, pemahaman, dan penghayatan umat Islam untuk dapat dikembalikan pada Islam yang mumi. Dan juga dalam rangka mengembangkan semangat ijtihad sehingga masyarakal (anggota Persatuan Islam) dapat dibebaskan dari sikap taqlid buta.

Dalam perkembangan selanjutnya menurut Azra termasuk kedalam kelompok New Revivalisme adalah gerakan Islam Jemaah, yang kemudian berganti menjadi Lembaga Karyawan Islam (lemkari). Dalam pandangan Islam Jamaah, pemahaman Islam telah dikaburkan oleh penafsiran yang berbelit-belit dari ulama. Upaya memahami Islam melalui kitab-kitab yang ditulis oleh ulama selain akan menghabiskan waktu belaka, juga hanya akan menimbulkan kekeliruan persepsi tentang Islam. Karena itu, umat Islam harus kembali langsung kepada Al-Qur'an dan Al-Hadis.

Banyak gerakan New Revivalis (pascamodemis) juga mempunyai kecendrungan yang kuat untuk melakukan hijrah dan setidaknya secara tak resmi melakukan tafsir terhadap mainstream Muslim. Conteh paling populer agaknya adalah gerakan Dar al Arkam yang mulanya muncul di Malaysia, tetapi kini juga popular dikalangan tertentu muslimin Indonesia. Revivalisme gerakan Dar al Arkam tidak hanya berupa pengambil alihan simbol-simbol lahiriyah yang mereka pandang sebagai perwujudan kembali ajaran "murni" Islam, seperti pakaian ala Arab dan jenggot, tetapi juga pembentukan komunitas perkampungan terpisah. Komunitas ekslusif 
Dar al Arkam, lebih jauh lagi, tidak hanya berupaya membangun sistem sosial budaya keagamaan "lebih 1slami", tapi juga berikhtiar menciptakan kehidupan ekonomi 1slami, dengan menciptakan usaha-usaha ekonomi yang dalam batas tertentu membuat mereka mandiri. Sejauh ini, Dar al Alkam kelihatan menjauhkan diri dari orientasi dan isuisu politik; dan dengan demikian gerakan hijrah mereka tidak mengarah kepada radikalisasi politik. Singkatnya gerakan revivalisme mereka lebih berorientasi kultural dan ekonomi ketimbang politik (Azra 2001: 49-54)

\section{Kesimpulan}

New revivalisme Islam adalah gerakan pemikiran Islam Kontemporer yang berusaha membersihkan dan mengembalikan pemahaman dan pengamalan ajaran Islam kepada Islam murni. New Revivalisme muncul disebabkan oleh permasalahan-permasalahan internal umat Islam dan Ekstemal dan pengaruh barat modem.

New Revivalisme di Pakistan muncul dibawah bumbingan tokoh utamanya yaitu Abul 'A'la Al Maududi dengan pendapat bahwa kehidupan umat Islam haruslah diatur berdasarkan ajaran Islam dalam suatu negara Islam, yang berbentuk "theo demokrasi”. Untuk terwujudnya negara yang demikian, perlu dilakukan revolusi Islam secara gradual, dengan terlebih dahulu melakukan Islamisasi masyarakat.

Hasan Al Bana dengan konsep Islam Kaffahnya melalui lkhwanu Muslimin berusaha mewujudkannya dengan mendaya gunakan semua potensi yang ada, baik secara individu maupun secara kelembagaan, sehingga Islam menjadi ldiologi yang konfrehensif, universal berdasarkan sumber aslinya; Al-qur'an dan Sunnah. Gerakan lkhwanu Muslimin menjadi radikal ditangan Sayyid Qutub, sehingga siap melakukan jihad fisabilillah. Di Indonesia juga ditemukan gerakan Revivalisme baik dalam bentuknya pramodernis maupun pascamodernis antara lain adalah gerakan padri, Muhammadiyah, Persatuan Islam, dan dalam bentuk yang lebih kini antara lain adalah Islam Jamaah dan Darul Arkam.

\section{Daftar Pustaka}

Azyumardi Azra. 1996. Pergolakkan Politik Islam. Jakarta : Paramadina.

--------------, 1999 Islam Reformis Dinamika lntelektual dan gerakan.Jakarta:PT. Raja Grafindo Persada.

Ali Rahmena. 1996 Para Perintis Zaman Baro Islam. Diterjemahkan dari Peoneers of Islamic Revival. Bandung : Mizan.

Ahmad Aziz. 1999. New-Modermisme Islam di Indonesia. Jakarta : PT. Rineka Cipta.

Ar Rahman Zainudin. 2000. Petunjuk Jalan. Diterjemahkan dari Ma'alim Fitthorik. Jakarta :Media Dakwah.

Asrarum Ni'am Shaleh. 2001. Gerakan Pengamalan Islam Secara Kaffah. Diterjemahkan darl Nahwa Wahdatin Fikhriah Lil Amelina Lil Islam. Karya Yusuf Kardawi. Jakarta :Penebar Salam.

Muhammad Al Bakhir. 19S8. Khilafah dan Kerajaan : Evaluasi Kritis Alas

Sejarah Pemerintahan Islam. Diterjemahkan dari Al Khilafah Waal Mulk karya Abu A'la Al Maududi. Bandung : Mizan.

Syafikh A Mukni.1994. Hasan Bandung Pemikir Islam Radikal. Surabaya: PT. Bina 1lmu.

M. Aunul Abied Shah. 2001 Islam Garcia Depan Mosaik Pemikiran Islam Timur Tengah. Bandung :Mizan 
Murkilim| New Revivalisme Islam 170 